\title{
УДК (373.1)
}

\section{Тичук Руслан Борисович}

викладач вищої категорії

Вінницький коледж НУХТ, м. Вінниця, Україна

ruslantytchuk@mail.ru

\section{Петрович Сергій Драганович}

канд. п. н., викладач вищої категорії

Вінницький коледж НУХТ, м. Вінниця, Україна

politex2004@rambler.ru

\section{ВИКОРИСТАННЯ ПРОГРАМ-ЕМУЛЯТОРІВ У НАВЧАННІ ФІЗИКИ МАЙБУТНІХ ТЕХНІКІВ ПРОГРАМІСТІВ}

\begin{abstract}
Анотація. Сучасна вимірювальна апаратура використовується спільно 3 цифровими i процесорними засобами управління та обробки інформації. Цифро-аналогові (ЦАП) $\mathrm{i}$ аналого-цифрові перетворювачі (АЦП) знаходять широке застосування в різних галузях сучасної науки і техніки. Пропонується використовувати на заняттях фізики та суміжних дисциплін ПК, як універсальний електровимірювальний прилад, в основі якого використовуються АЦП І ЦАП звукового адаптера з акцентом на використанні елементи, засоби і принципи програмування в його програмному забезпеченні.

У дослідженні розглядається два аспекти: методика навчання фізики, набуття професійних компетенцій техніків-програмістів.
\end{abstract}

Ключові слова: аудіоадаптер; програми-емулятори; реальний і віртуальний навчальний фізичний експеримент; професійні компетенції, професійна компетентність.

\section{1. ВСТУП}

Існує кілька способів використання сучасних цифрових осцилографів на заняттях 3 фізики: придбати вартісний автономний цифровий осцилограф з високим класом точності; придбати, або створити приставку до ПК з порівняно високим класом точності (у якій буде програмно керуючий АЦП) та підключити до USB або LPT порт (але ціна також буде високою й оцінюється кількома тисячами гривень) i найоптимальніший спосіб використання АЦП - від звукового адаптера ПК.

Використання ПК, як універсального електровимірювального приладу досить поширено серед радіолюбителів i, на наш погляд, має зайняти чільне місце в методичному забезпеченні викладача фізики. Базова конфігурація ПК вже містить найпростіший пристрій збору й обробки звукових даних - звуковий адаптер. У сучасних ПК він, зазвичай, інтегрований у системну плату. Властивості аудіоадаптера 3 обробки інформації сприяли створенню радіолюбителями програм, які емулюють роботу таких вимірювальних приладів як осцилограф, спектроаналізатор, звуковий генератор, вольтметр, частотомір тощо. Більшість із них є вільними для використання 3 некомерційною метою. Тому, маючи ПК з невисокими технічними характеристиками, викладач фізики може отримати у своє розпорядження одну 3 модифікацій вимірювального комплексу на основі ПК [5].

Студенти, майбутні техніки-програмісти, природно, що цікавляться програмуванням, тому гурткова робота з комп'ютерного моделювання фізичних явищ, сприяє поглибленому вивченню програмування i активізує вивчення фізики у технічному коледжі.

Постановка проблеми. Після вивчення основних властивостей і можливостей програмного забезпечення існуючих аналогів програм-емуляторів вимірювальних 
приладів ми дійшли висновку, що необхідно створити власний універсальний вимірювальний прилад-емулятор для вивчення електромагнітних коливань. Для студентів спеціальності «Комп'ютерна інженерія» він використовується разом 3 розробленим програмним кодом. Даний код $\epsilon$ «відкритим вихідним програмним кодом». Студенти аналізують та працюють над покращенням лістингу програми. Отже, забезпечується використання міжпредметних зв'язків: фізики, математики, програмування. Це сприяє створенню педагогічних умов, які впливають на формування професійних компетентностей майбутніх техніків-програмістів. Важливими умовами реалізації міжпредметних зв'язків є: дотримання певних вимог щодо встановлення взаємозв'язків у процесі вивчення фізико-математичних дисциплін та програмування; реалізація принципу професійної спрямованості змісту фізико-математичних дисциплін; формування міжпредметних знань, умінь та навичок; визначення шляхів i методів реалізації міжпредметних зв'язків. Вміле поєднання інформаційнокомунікаційних технологій і традиційних методів викладання фізики 3 елементами програмування можуть мати бажаний результат: високий рівень засвоєння знань 3 фізики й усвідомлення їх практичного застосування, а також оволодіння основними прийомами і методами програмування.

Аналіз останніх досліджень і публікацій. Проблемам удосконалення змісту, методики та техніки навчального фізичного експерименту 3 застосуванням комп'ютерних технологій у навчальному процесі присвячено роботи О.І. Бугайова, С. П. Величка, М.Ф. Вукса, В. Ф. Заболотного, О.М. Желюка, Ю.О. Жука, Л.Р. Калапуші, В. Ю. Кліха, О.І. Ляшенка, О.С. Мартинюка, В. Ф.П'яних та ін. Дослідженню проблем залучення програмно-апаратних засобів для постановки навчального експерименту з фізики присвячували свої публікації Ю.П. Бендес, О.І. Денисенко, Я.Ю. Дима,О.С. Мартинюк, О.П. Руденко, О.В. Саєнко,В .І. Тищук, та інші. Проте, досі не повністю $€$ вирішеним питання формування професійних компетентностей майбутніх техніків-програмістів засобами інформаційнокомунікаційних технологій у професійній підготовці студентів. Дослідженням змісту професійної компетентності програмістів та її елементів займалися М.С. Головань, Н.В. Кузьміна, А.К. Маркова, С.А.Раков, В. О. Сластьонін, Ю.В.Триус, А.В. Хуторський та інші науковці.

Аналіз педагогічної, технічної та іншої літератури [4-6] і власний педагогічний досвід використання комп'ютерних засобів дає підстави стверджувати, що нині впровадження інформаційно-комунікаційних технологій у процес навчання техніківпрограмістів, $є$ актуальною проблемою, яка потребує наукового, експериментального та методичного обгрунтування і подальшого дослідження.

Основу дослідження склала гіпотеза: інтеграція реального фізичного експерименту, сучасних технологій програмування та дослідження програмного коду програми, яка використовується для вимірювання фізичних величин. Даний підхід сприяє розвитку дослідницької діяльності студентів, формуванню професійних компетентностей майбутніх техніків-програмістів. Таким чином забезпечується відповідність змісту навчального процесу з фізики сучасному рівню розвитку науки i техніки, технічна направленість навчання. Адже ПК використовується як інструмент під час проведення фізичного експерименту, а розробка й аналіз студентами програмного коду сприяють створенню педагогічних умов, які впливають на формування професійних компетентностей майбутніх техніків-програмістів.

Метою статті $\epsilon$ обгрунтування використання програм-емуляторів вимірювальних приладів під час демонстрацій і проведення лабораторних робіт з фізики в контексті формування професійних компетентностей майбутніх техніків-програмістів. 


\section{2. РЕЗУЛЬТАТИ ДОСЛІДЖЕННЯ}

У дослідженні використано міжпредметні зв'язки таких дисциплін: фізика, математика, програмування, системне програмування.

Важливим $\epsilon$ i той факт, що сучасне програмування $\epsilon$ колективним, i робота окремого програміста тісно пов'язана з його корисністю для всієї команди, а тому вимагає від робітника навичок роботи у команді, комунікаційних якостей, певних знань 3 галузі психології й управління. На нашу думку, особливістю успішного IT-спеціаліста $\epsilon$ не деякий фіксований набір знань, умінь і навичок у галузі програмування, а сформованість комплексу компетентностей, які забезпечують майбутнє кар'єрне зростання. Побудова навчального процесу саме на засадах компетентнісного підходу $є$ найефективнішою для забезпечення підготовки майбутнього фахівця відповідно до сучасних вимог суспільства [3].

Компетенція в перекладі з латинської competencia означає коло питань, у яких людина добре обізнана, володіє знаннями і досвідом; competens (лат.) - відповідальний, обізнаний; competere (лат.) - здатний зробити професійно, бути відповідним; competence (англ.) - здібність (компетенція) [9]. В енциклопедичному словнику поняття “компетенція" трактовано як коло повноважень, питань, в якому певна особистість має досвід, знання.

Професійна компетентність розглядається як системна, інтеграційна єдність, синтез інтелектуальних і навичкових складових (загальні знання, вміння і навики), особистісних характеристик (ціннісні орієнтації, здібності, риси вдачі, готовність до здійснення своєї діяльності) і досвіду, що дозволяє використовувати свій потенціал, здійснювати складні види діяльності, оперативно і успішно адаптуватися в суспільстві i професійній діяльності [10]. Такими компетентностями є:

1) готовність і здатність спонукати інших людей працювати спільно заради досягнення поставленої мети;

2) готовність і здатність робити що-небудь ефективніше, ніж раніше;

3) готовність і здатність вирішувати складні питання;

4) готовність і здатність виступати зі своїми новими ідеями;

5) готовність і здатність посідати керівні посади;

6) готовність і здатність вчитися все життя як основа безперервної підготовки в професійному плані;

7) готовність і здатність навчатися самостійно [10].

Розглядаючи професіоналізм програміста, науковці (Е.В.Дейкстра, М.Л. Смульсон, Б. Шнейдерман) виділяють якості, які йому властиві, що пов'язані безпосередньо із створенням програмного продукту, психологічні й загальнолюдські риси, які повинні бути притаманні програмісту [8].

У галузевому стандарті напрямку підготовки «Інформатика» наведено такі означення: компетентність - інтегрована характеристика якостей особистості, результат підготовки випускника ВНЗ для виконання діяльності в певних професійних і соціально-особистістних предметних галузях (компетенціях), який визначається необхідним обсягом і рівнем знань і досвіду в певному виді діяльності. Компетенція включає знання й розуміння (теоретичне знання академічної галузі, здатність знати й розуміти), знання як діяти (практичне й оперативне застосування знань до конкретних ситуацій), знання як бути (цінності як невід'ємна частина способу сприйняття й життя 3 іншими в соціальному контексті) [5].

У рамках компетентнісного підходу акцент має бути зміщено від формування певного набору професійних знань, умінь і навичок у галузі програмування на виховання таких якостей, як робота в команді, лідерські якості, відповідальність, 
здатність до рефлексії, здатність до самостійного навчання й освоєння нових технологій протягом життя, самоосвіта, планування діяльності, логічне й алгоритмічне мислення, цілеспрямованість, наполегливість, уміння самостійно ухвалити рішення, швидко адаптуватися до нового завдання, широкий кругозір у предметній галузі. Попри це, виникає затребуваність у специфічних знаннях психології й менеджменту, зокрема, управління проектами [11].

Створений нами «Електронний комплекс для дослідження електромагнітних коливань» використовується у вивченні дисциплін: «Фізика» (5 лабораторних занять), «Електрорадіовимірювання» (3 лабораторних заняття), «Комп’ютерна електроніка» (5 лабораторних занять) та може бути використаний на лабораторних і лекційних заняттях для аудиторного експерименту, у вивченні інших спеціальних дисциплін у технічних коледжах. Методику використання на лабораторних заняттях з фізики аналогів описано в літературі [4-6].

У процесі вивчення фізики у технічному коледжі «Електронний комплекс для дослідження електромагнітних коливань» використовується як демонстрація фізичних явищ 3 акустики i електромагнетизму на лекційних та лабораторних заняттях: «Дослідження змінного струму за допомогою осцилографа», «Вимірювання швидкості звуку у повітрі методом інтерференції», «Дослідження додавання коливань в одній площині», «Дослідження складання взаємоперпендикулярних електромагнітних коливань», «Дослідження гістерезису феромагнітних матеріалів». Корисним і важливим $\epsilon$ те, що студенти можуть вивчити основи використання програмного забезпечення приладу в домашніх умовах, оскільки є можливість скачати його 3 мережі Інтернеті мати доступ до програмного коду.

У процесі вивчення фізики (2 курс), студенти уже мають деякі навички структурного програмування, оскільки вивчають дисципліну «Алгоритми і методи обчислень». 3 метою розвитку професійних компетентностей і активізації пізнавальної діяльності на лекційних, практичних і лабораторних заняттях у процесі використання власного програмного забезпечення демонструється програмний код реалізації тих чи інших програмних рішень, в тому числі фізичних задач. Один з важливих моментів у використанні власного програмного забезпечення є наявний вихідний програмний код. Тому при знайомстві 3 програмним забезпеченням даного електронного комплексу зроблено акцент на таких засобах в технологіях програмування, які студенти будуть вивчати у вивченні дисциплін «Системне програмування» і «Програмування»: робота 3 регіонами (візуальні об'єкти неправильної форми, (рис. 2), робота 3 іпі-файлами (запис конфігурації налаштувань програми у файл), робота зі звуком, робота 3 графікою (в тому числі візуальні можливості та використання класу Chart), робота 3 масивами, підключення сторонніх додаткових компонентів до середовища програмування, використання технології перетягування візуальних об'єктів DragOnDrop, використання асемблерних вставок, використання зовнішньої бібліотеки AlphaControls («скінів») та інші. Майбутні техніки-програмісти у технічному коледжі на другому та третьому курсі вивчають мову програмування C++, а на четвертому - C\#, Delphi, Java.

Гурткова робота сприяє більш інтенсивному вивченню програмування, набуттю навичок виготовлення фізичних приладів, а також формуванню професійних компетентностей майбутніх техніків-програмістів. Так використовуючи метод проектів, студенти отримують досвід роботи в команді і вміння працювати самостійно. Досліджуючи програмний код не лише даного програмного засобу, а й власних програмних розробок, вивчають основи програмування i сучасні методи програмування, розробляють нові і вдосконалюють вже існуючі програмні засоби. А в процесі вивчення дисциплін «Системне програмування» $\mathrm{i}$ «Програмування» здійснюється аналіз існуючого програмного коду для реалізації можливостей i 
застосування методів і технологій програмування і відбувається повторення основних фізичних явищ. Причому в процесі проведення гуртка студенти вивчають синтаксис мов програмування.

Розроблений нами вимірювальний комплекс на базі ПК, має програмну частину (програмне забезпечення комплексу) i апаратну частину - пристрій-приставку (дільник напруги), сигнал з якого подається на мікрофонний вхід звукового адаптера ПК. На рисунку 1 подано одну із можливих схем двохканального дільника напруги, що $є$ апаратною частиною «Електронного комплексу дослідження електромагнітних коливань, а програмна частина складається з 9 модулів, які реалізують три віртуальні двоканальні прилади: осцилограф, генератор сигналів, спектроаналізатор. Програмне забезпечення розроблене на мові програмування Delphi. Аналоги електричних схем i програмного забезпечення досить часто зустрічаються на сайтах радіолюбителів, алепроаналізувавши можливості таких безкоштовних засобів і сучасних вартісних цифрових та віртуальних USB-осцилографів, ми прийшли до висновку, що необхідно розробити власне програмне забезпечення для вимірювального комплексу на основі звукового адаптера, яке буде досить дешевим і достатньо дієвим в електричних вимірюваннях (точність вимірювань достатня для навчального процесу) порівняно 3 аналогами.

Вдало скомпонований вимірювальний комплекс на базі ПК надає більші можливості порівняно 3 традиційними вимірювальними приладами 3 аналогічним рівнем технічних характеристик, адже реалізує великий набір методів вимірювання, аналізу та відображення інформації, $є$ гнучким у керуванні. За його допомогою можуть проводити вимірювання не лише фахівці з радіоелектроніки, а й викладачі та студенти технічного коледжу. Входом в ПК потрібно обрати мікрофонний вхід, а виходом генератора - вихід на колонки. Щоб убезпечити дослід від спотворення результатів, решту пристроїв краще відключити (для уникнення «акустичної зав'язки», усунення «додаткових шумів» тощо). Також слід перевірити положення повзунків «Гучність» та «Баланс» як для запису, так і для відтворення і встановити на максимум або середнє положення (тоді легко відтворити дослід в наступний раз). Бажано відключити звуки, що супроводжують події операційної системи Windows та інших програм.

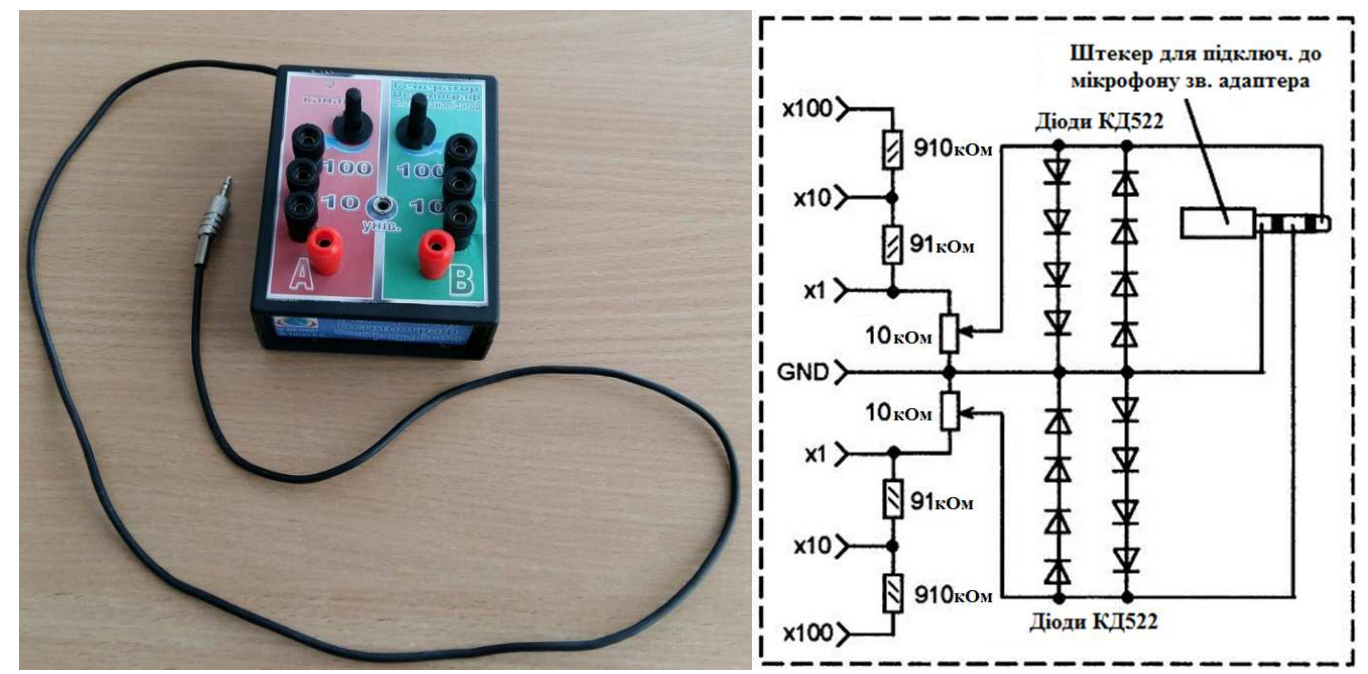

Рис. 1. Апаратна частини осиилографата ї̈ електрична схема

Можливості такого вимірювального комплексу дозволяють використовувати його в якості таких приладів: вольтметр, амперметр, частотомір, осцилограф, звуковий 
генератор, самописець (для визначення малих інтервалів часу при дослідженні електричних сигналів).

Розглянемо основні можливості вимірювального комплексу і його програмну реалізацію, яка досліджується в процесі проведення гуртка. На рисунку 2 показано головне вікно програмного забезпечення «Електронного комплексу для дослідження електромагнітних коливань» форма якого є неправильною і вирізи на формі реалізовані із застосуванням регіонів.

Даний «Електронний комплекс для дослідження електромагнітних коливань» містить три додатки: генератор сигналів, осцилограф і спектроаналізатор.

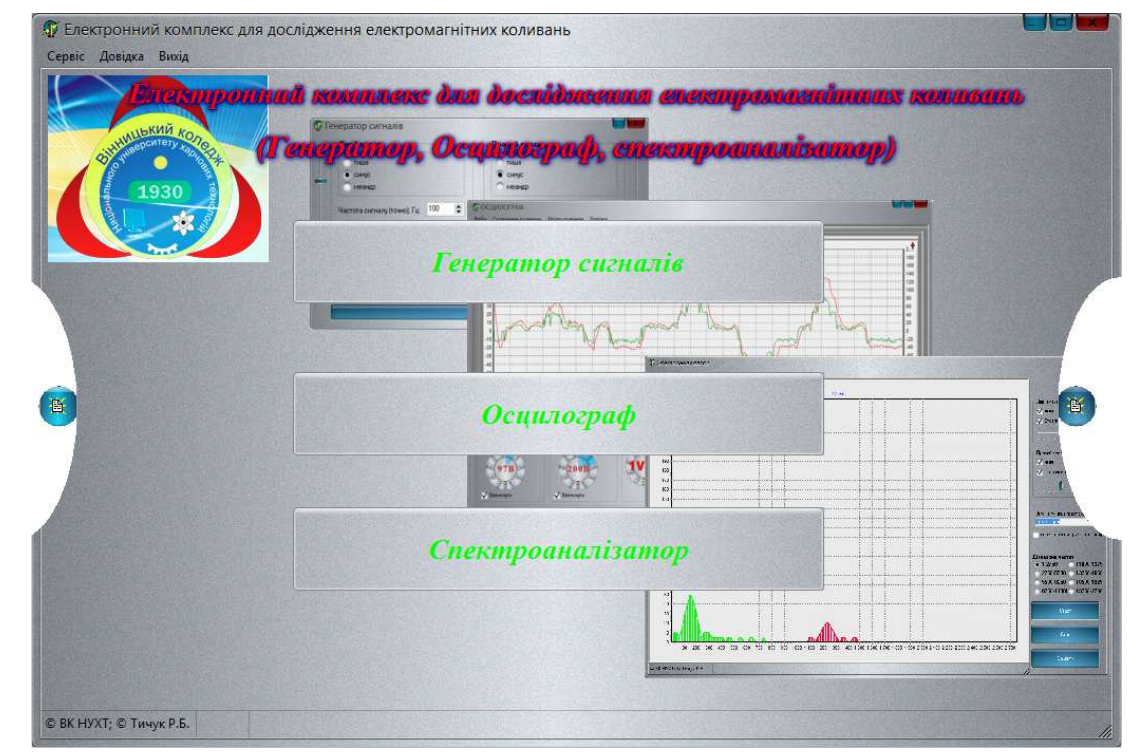

Рис. 2. Головне вікно «Електронного комплексу для дослідження електромагнітних коливань»

Генератор сигналів дозволяє створювати двасигнали за формою синусоїди або меандр із заданими параметрами: частотою, амплітудою, фазою (рис. 3). На прикладі програмного коду реалізації генератора демонструється використання асемблерних вставок, адже досить часто студенти цікавляться як використовується в сучасних програмах мова програмування низького рівня асемблер. Даний програмний код демонструє роботу мікшера звуку (змішування двох масивів даних (каналів) FirstiSecond, змішує масиви і розміщує результат в масив Buffer) з використанням асемблерної вставки і використанням стеку.

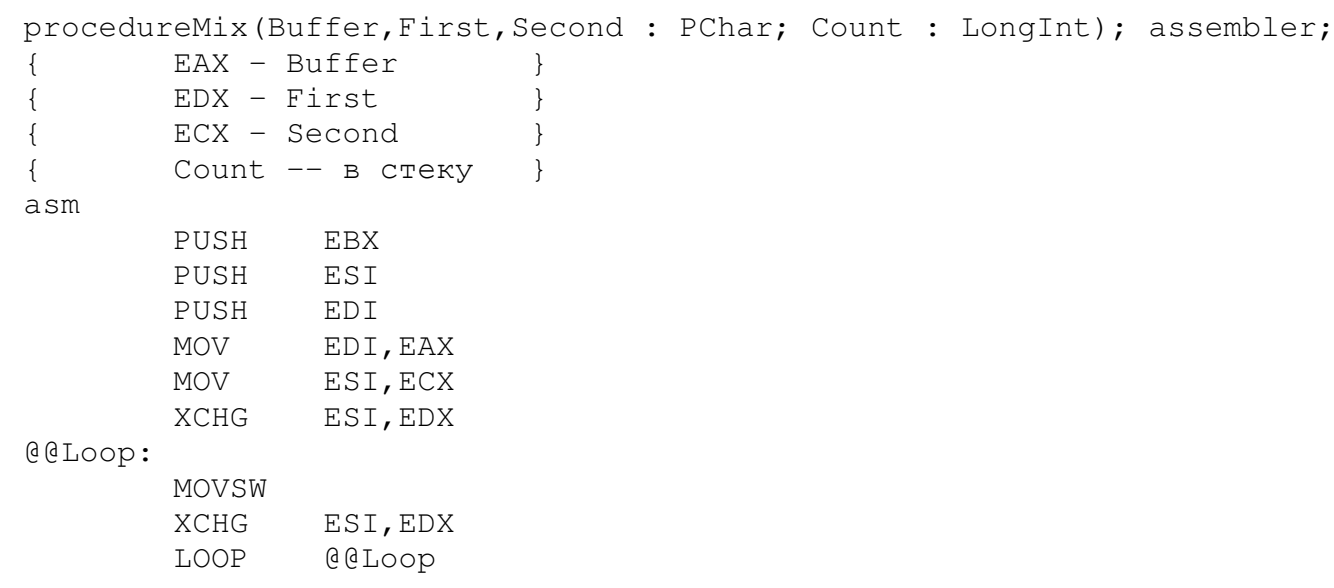




$\begin{array}{lll} & \text { POP } & \text { EDI } \\ & \text { POP } & \text { ESI } \\ & \text { POP } & \text { EBX } \\ \text { end; } & & \end{array}$

Демонстрація вивчення характеристик звуку подається як створення потоку даних в програмі «Генератор». Фізична демонстрація відбувається зпоясненням програмного коду програми:
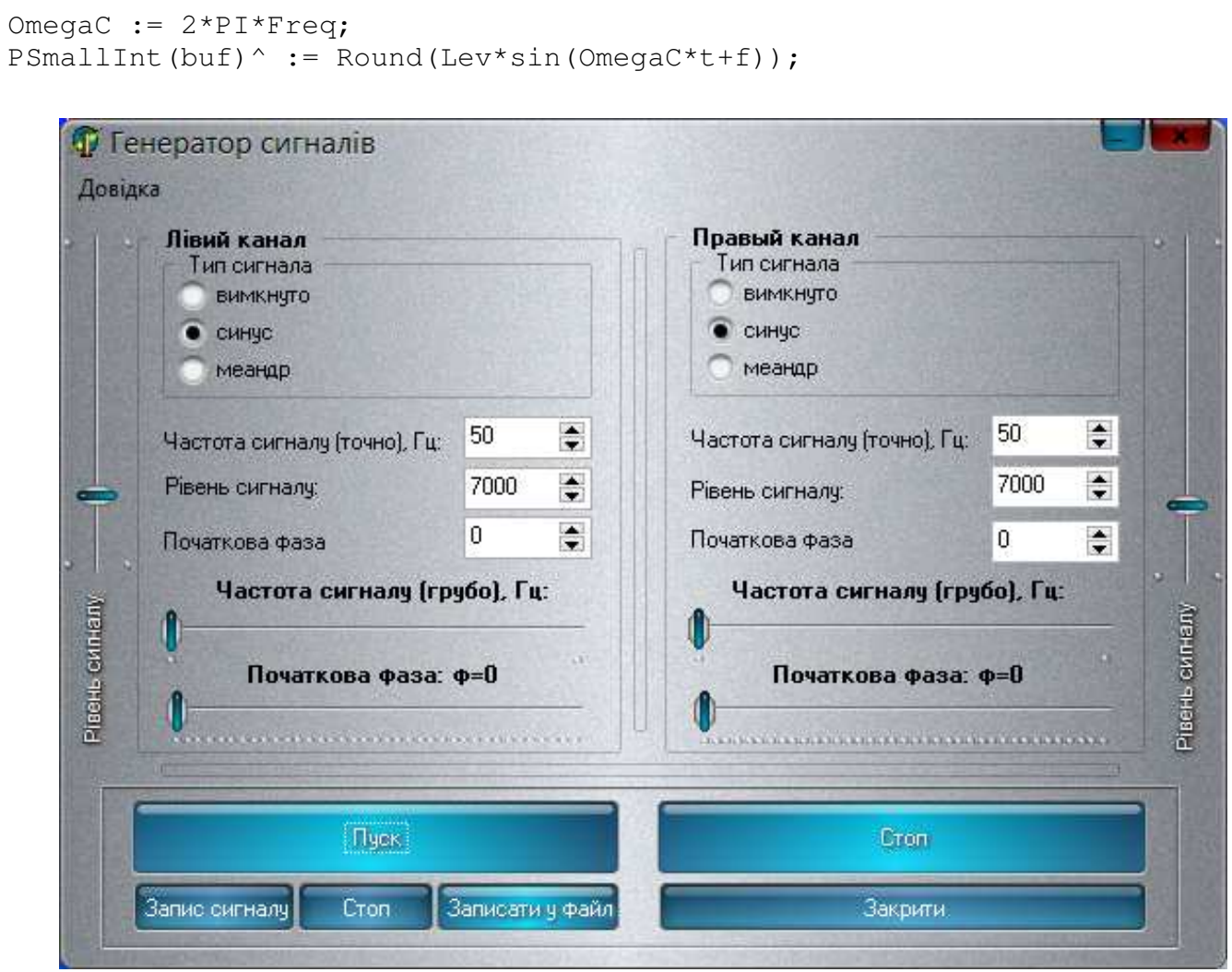

Рис. 3. Вікно «Генератор сигналів»

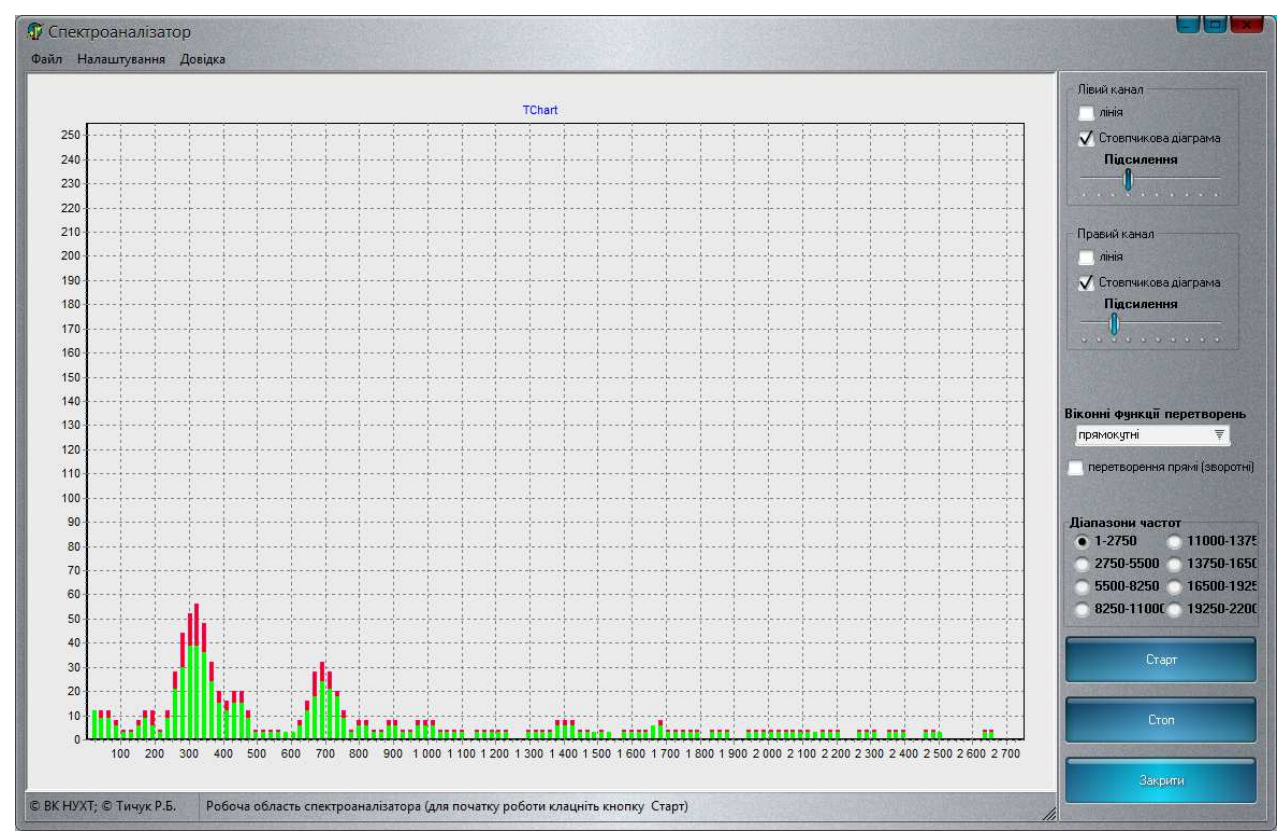

Рис. 4. Вікно «Спектроаналізатор» 
Демонстрація використання стовпчикової діаграми реалізована в спектроаналізаторі (рис. 4). Робота програмного модуля заснована на загальній методиці дослідження сигналів, в основі якої розкладання сигналів вряд Фур'є при допомозі алгоритму швидкого обчислення дискретного перетворення Фур'є, FastFourierTransform (FFT). Спектроаналізатор - прилад для вимірювання i відображення спектра сигналу. За його допомогою відбувається розподіл енергіїсигналу по частотах. Використовуються спектроаналізатори в акустиці, наприклад, у процесі дослідження характеристик шуму, при розробці і обслуговуванні аудіоапаратури та ін.

Третім приладом-емулятором із створеного вимірювального комплексу $\epsilon$ осцилограф. На рисунку 5 подано вікно емулятора осцилографа при осцилографуванні звуку, що знімається з мікрофона.

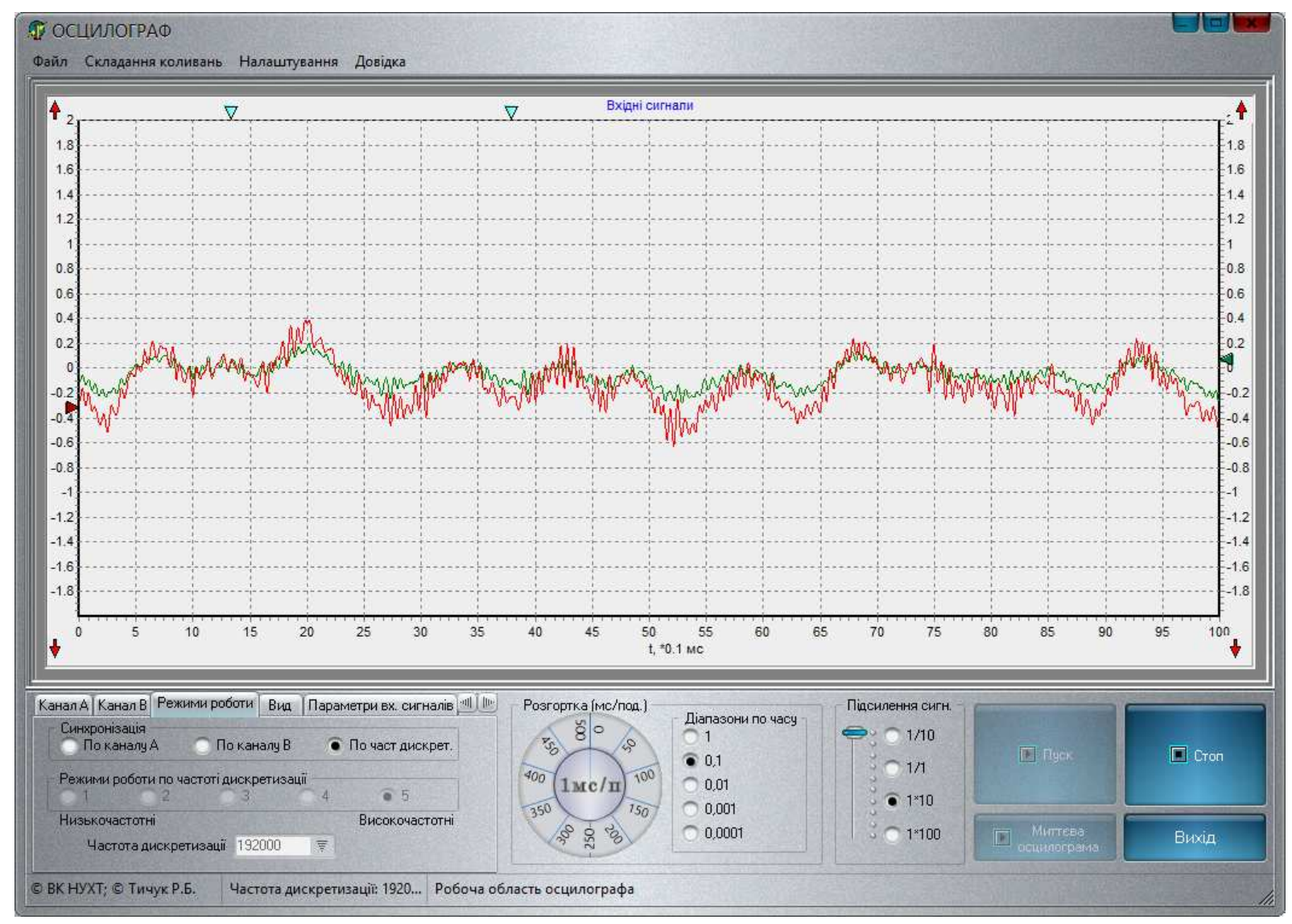

Рис. 5. Вікно «Осцилограф» при осцилографуванні звуку

Функціонал закладки «Режими роботи» панелі керування дозволяє обирати режим роботи по частоті дискретизації. Також можна вибрати синхронізацію сигналів по першому чи другому сигналу, або частоті дискретизації. Як осцилограф використовується даний прилад у процесі вивчення акустики і вивченні змінного струму, а також електромагнітних коливань.

Студенти мають можливість не тільки ознайомитись 3 принципом дії i програмним забезпеченням приладу в домашніх умовах, а навіть досліджувати різні сигнали 3 малою амплітудою коливань напруги (до 2 вольт) і виконувати творчі завдання (проекти) з використанням акустики і змінного струму. Також при цьому вони використовують широкі графічні можливості компоненту TChart. 
На рисунку 6 показано вікно при осцилографуванні музичного тону, для дослідження сигналу можна використовувати маркери, зміна положення яких реалізована на основі технології перетягування візуальних об'єктів DragOnDrop, a значення параметрів (що обираються безпосередньо із значень компонента класу TChart) під маркерами відображаються на закладці «Маркери і вхідні сигнали» панелі керування. Функціонал цієї закладки дозволяє записувати і відтворювати вхідні сигнали, запис здійснюється у файл формату wav. За таким принципом працює диктофон. На прикладі розробленого програмного коду студентам пропонується створити власний диктофон. Наступний програмний код демонструє найпростішу команду відтворення звукового файлу.

mciSendString(PChar('play ' + OpenDialogl.FileName), nil, 0, Handle);

Також увага студентів, у процесі аналізу програмного коду, акцентується на тому, що принцип використання функцій WinAPI, та інших спеціальних програмних модулів однаковий в різних мовах програмування і наводяться конкретні приклади.

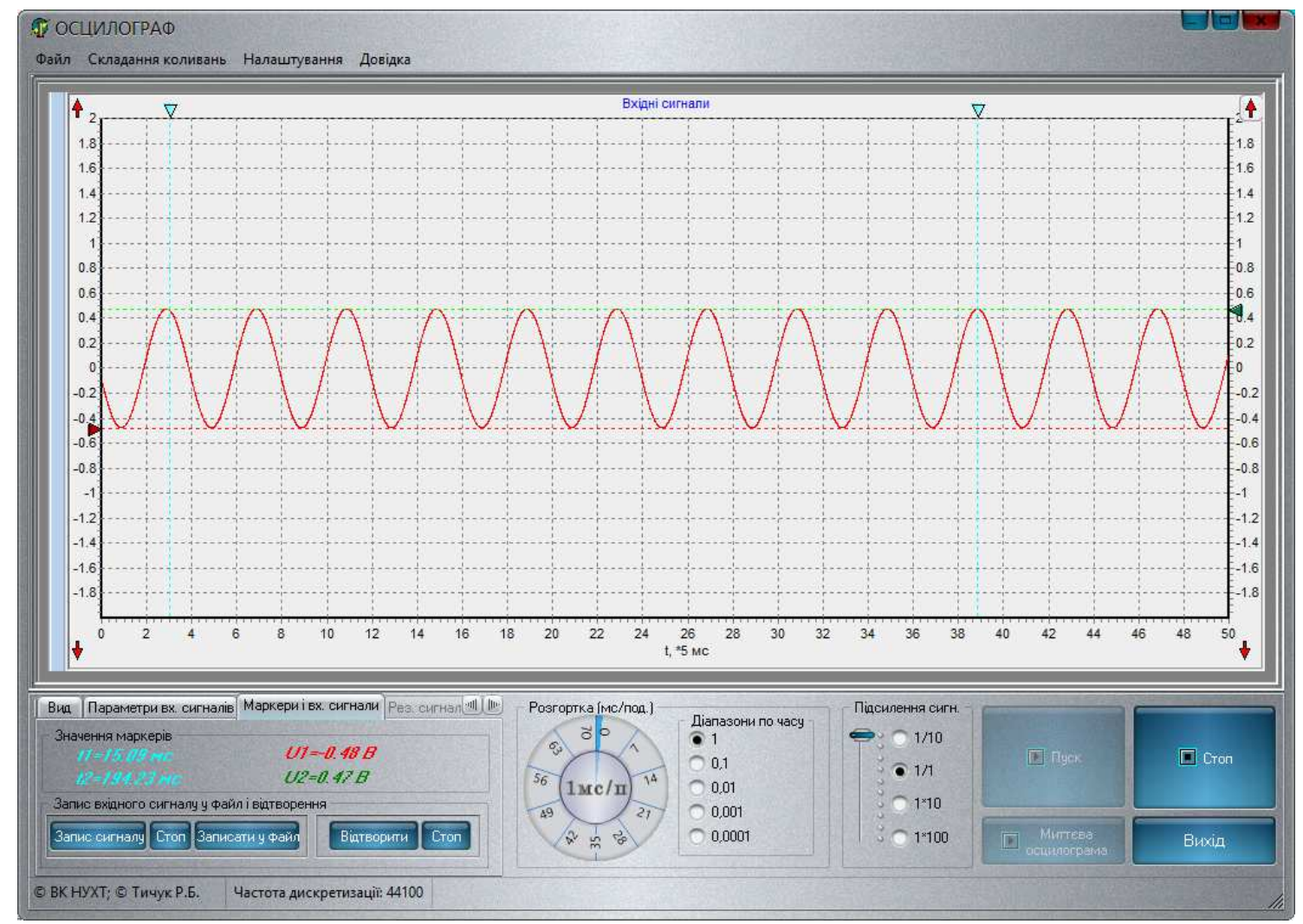

Рис. 6. Вікно «Осиилограф» при осцилографуванні гармонічного сигналу

Осцилограф дозволяє складати одно направлені (рис. 7) та взаємоперпендикулярні (рис. 8) коливання, причому можна відображати їх одночасно 3 вхідними сигналами. На рисунку 7 на панелі управління відкрита закладка, що відображає основні параметри вхідних сигналів, які можна використати на лабораторних роботах для вимірювання параметрів вхідних сигналів: напруги, частоти, малих інтервалів часу, сили струму (враховуючи опір включений послідовно в коло).

На рисунку 8 показано вікно в процесі спостереженні фігур Ліссажу (складання взаємноперпендикулярних коливань). С можливість відображати результуючий сигнал, або в комбінації результуючий і вхідні сигнали. Закладки «Канал А» $\mathrm{i}$ «Канал В» 
дозволяють керувати параметрами відображення вхідних сигналів. Вмикати, вимикати сигнал; вказувати клеми на які подається вхідний сигнал, а також подавати сигнал або 3 звукового адаптера, або безпосередньо програмно від генератора (ідеальний чистий сигнал), оскільки навіть дуже якісний звуковий адаптер створює власні мікрошуми, які спотворюють дуже малі за амплітудою сигнали (але в цілому прилад є чутливим, можна вимірювати сигнали до долей мілівольт). Для програмного підсилення сигналу служить панель «Підсилення сигн.», яка розміщена на панелі керування, а також можна калібрувати вхідні сигнали за допомогою круглих ручок на апаратній частині приладу. Круглі елементи управління на панелі керування створені для масштабування графічної залежності по часу (панель «Розгортка») і по амплітуді (закладки«Канал А/В»).

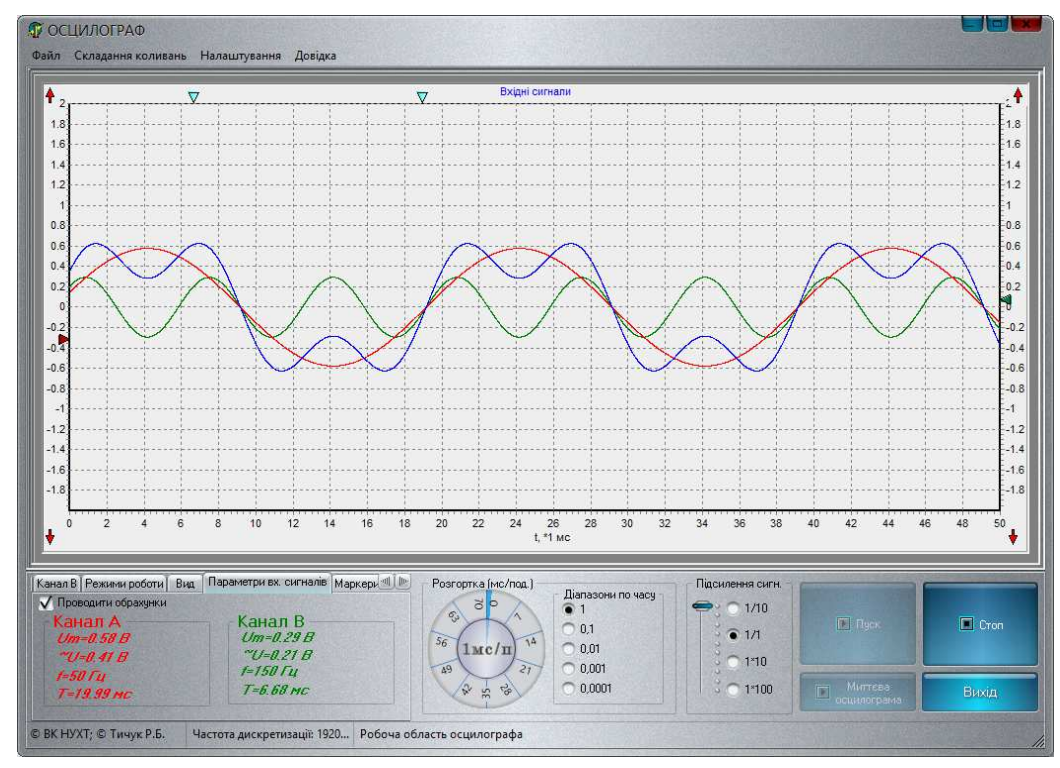

Рис. 7. Вікно «Осцилограф» при осцилографуванні складання двох однонаправлених коливань

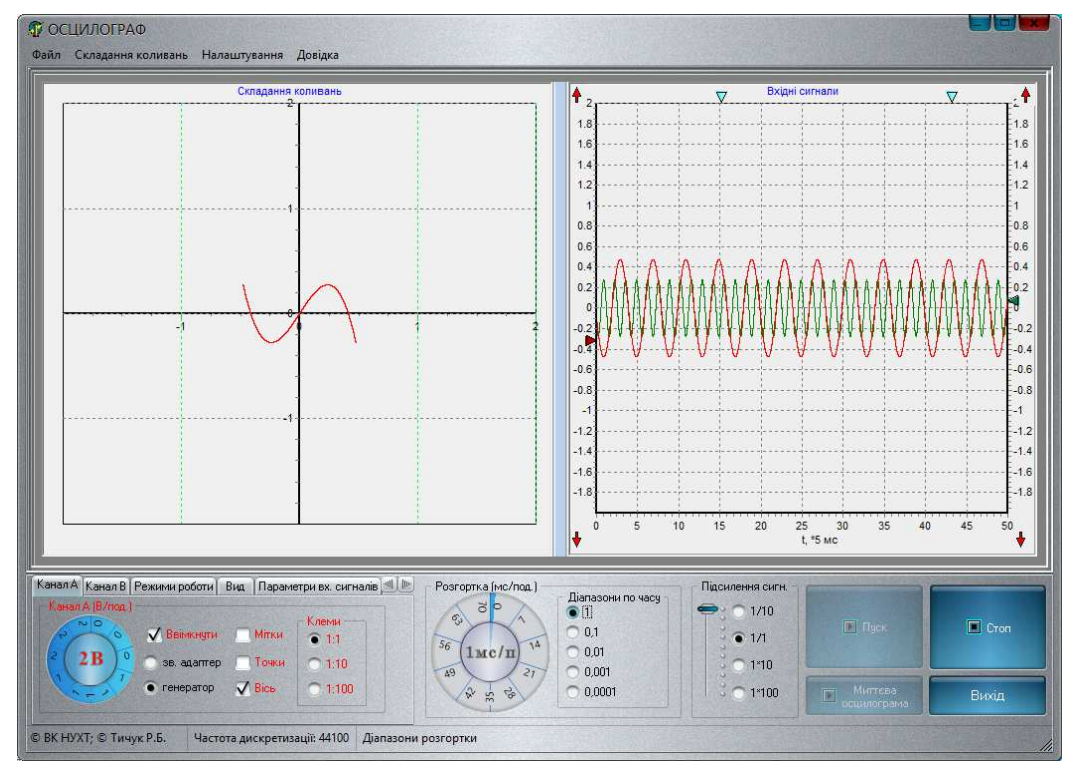

Рис. 8. Вікно «Осциилограф» при осиилографуванні складання двох взаємноперпендикулярних коливань 
У процесі проведення гурткової роботи для вивчення поняття «Музичні ноти» доцільно використати завдання створення найпростішого звукового генератора 3 використанням функції Веер, а також створення мелодій на їх основі. На основі відомостей про музичні ноти і акустику студенти створюють графічний синтезатор звуку. Далі показано приклад програмного коду, який демонструє програвання мелодії.

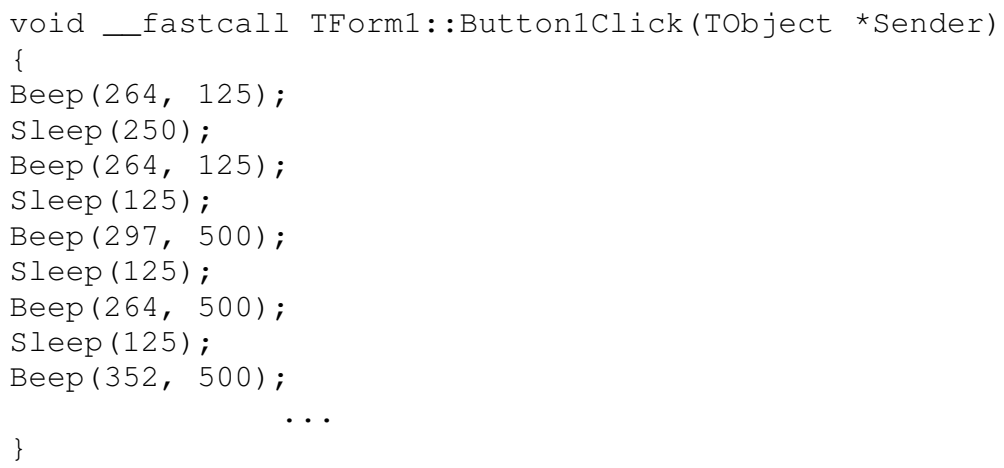

У Вінницькому коледжі НУХТ під час використання лабораторного практикуму і фізичних демонстрацій із використанням ПК викладачі надають перевагу застосуванню програм-емуляторів, а не програм симуляторів. А в процесі організації гурткової роботи використовуються дослідні проекти, які потребують знань 3 фізики та програмування.

\section{3. ВИСНОВКИ ТА ПЕРСПЕКТИВИ ПОДАЛЬШИХ ДОСЛІДЖЕНЬ}

Простота описаного методу організації навчального експерименту 3 фізики, доступність відповідного програмного забезпечення з відкритим програмним кодом, інтенсивна гурткова робота 3 програмного моделювання фізичних процесів, дозволяють створювати експериментальні установки на основі ПК. Так створюються педагогічні умови для формування професійних компетентностей майбутніх техніківпрограмістів. Це відкриває можливості як для позааудиторної роботи 3 фізики i програмування, так і для створення підгрунтя подальшого вивчення методів програмування і підвищення мотивації донавчання.

Зазначимо, що важливе завдання викладача полягає в створенні педагогічних умов для поетапного створення можливості для студентів управляти дією механізмів стабілізації, доповнення й трансформації своєї професійної компетентності. Етапи нарощування умов такі: управління викладачем діяльністю студента; спільне керування викладачем і студентом механізмами функціонування професійної компетентності; самоуправління майбутнім фахівцем процесом професійного саморозвитку.

Отже, використання вищеописаних методів у практиці викладання фізики у технічному коледжі буде сприяти створенню педагогічних умов, які впливають на формування професійних компетентностей, а також професійно значущої спрямованості діяльності студентів.

Важливе значення у формуванні професійних компетентностей фахівця IT-галузі нині належить програмам-емуляторам вимірювальних приладів й інформаційнокомунікаційним технологіям. Розроблені викладачами Вінницького коледжу НУХТ програми-емулятори, $€$ складовою частиною освітньої системи становлення й формування професійних компетентностей майбутнього техніка-програміста, вони сприяють первісному створенню професійно-ціннісної бази оволодіння професією, 
поступовому формуванню теоретичної, практичної й мотиваційної готовності й здатності здійснювати професійну діяльність на високому рівні.

\title{
СПИСОК ВИКОРИСТАНИХ ДЖЕРЕЛ
}

1. Беспалов П. В. Компьютерная компетентность в контексте личностноориентированного обучения/ П. В. Беспалов // Педагогика. - №4. - 2003. - С.41-45.

2. Вінник М.О. Формування дослідницьких компетентностей студентів спеціальності «Програмна інженерія» на прикладі викладання курсу «Групова динаміка та комунікації»/ Вінник М.О., Осипова Н.В., Тарасіч Ю.Г., Савенко А.П., // Наукові праці: Наук.-метод. журнал. - Вип. 216. Педагогіка. - Миколаїв: Вид-во ЧдУ ім. Петра Могили, 2014.

3. Галузевий стандарт вищої освіти України. Освітньо-кваліфікаційна характеристика бакалавр. Галузь знань 0403 Системні науки та кібернетика. Напрям підготовки 040302 Інформатика. Міністерство освіти і науки України. - К., 2010. - 32 с

4. Дима Я. Методичні аспекти використання програм-емуляторів вимірювальних приладів у демонстраційному експерименті на уроках фізики / Я. Дима, О. Саєнко // Наукові записки Тернопільського національного педагогічного університету ім. В. Гнатюка. Сер. Педагогіка / гол. ред. Г. Терещук. - Тернопіль, 2011. - № 1. - С. 135-140.

5. Дима Я. Ю. Проведення лабораторних робіт з фізики із застосуванням інтерактивних методик та комп'ютерної техніки / Я. Ю. Дима, О. П. Руденко, О. В. Саєнко // Збірник наукових праць Уманського державного педагогічного університету імені Павла Тичини. - Умань : ПП Жовтий О. O., 2009. - Ч. 2. - C. 99-106.

6. Лаврова А.В. Підхід до організації і проведення шкільного навчального фізичного експерименту / Лаврова А.В, Заболотний В.Ф.//Інформаційні технології і засоби навчання, 6 (50)

7. Леонтян М. А. Поняття "компетенція" і "компетентність" у теорії освіти / М. А. Леонтян // Наукові праці Чорноморського державного університету імені Петра Могили комплексу "КиєвоМогилянська академія"]. Сер.:Педагогіка. - 2012. - Т. 188, Вип. 176.-С.73-75.

8. Осипова Н. Модель формування дослідницької компетентності у майбутніх інженерівпрограмістів / Н. Осипова, М. Вінник, Ю. Тарасіч // Інформаційні технології в освіті. - 2014. Вип. 20. - С. 150-159.

9. Петрович С. Д. Формування професійної компетентності у майбутніх фахівців з обчислювальної техніки в процесі вивчення спеціальних дисциплін в технічних коледжах: Дис. канд. пед. наук: 13.00.04/С.Д. Петрович; Вінниц. держ. пед. ун-т ім. М. Коцюбинського. - Вінниця, 2011. - 255 с.

10. Радельчук Г. І. Формування професійних компетенцій сучасного інженера-програміста // Збірник наукових праць факультету прикладної математики та комп'ютерних технологій Хмельницького національного університету.- Хмельницький:ХНУ.- № 1 (2).- 2009. - С. 142-147.

11. Щедролосьєв Д.Є. Компетентнісний підхід до підготовки інженерів-програмістів//Д.Є. Щедролосьєв, 2011, Інформаційні технології і засоби навчання. 2011. №4 (24). Режим доступу до журналу: http://www.journal.iitta.gov.ua

Матеріал надійшов до редакиіï 30.10.2016 p.

\section{ИСПОЛЬЗОВАНИЕ ПРОГРАММ-ЭМУЛЯТОРОВ ПРИ ИЗУЧЕНИИ ФИЗИКИ БУДУЩИХ ТЕХНИКОВ ПРОГРАММИСТОВ}

\author{
Тычук Руслан Борисович \\ преподаватель высшей категории \\ Винницкий колледж НУПТ, г. Винница, Украина \\ ruslantytchuk@mail.ru
}

Петрович Сергей Драганович

канд. п. н., преподаватель высшей категории

Винницкий колледж НУПТ, г. Винница, Украина

politex2004@rambler.ru

Аннотация. Современная измерительная аппаратура давно срослась с цифровыми и процессорными средствами управления и обработки информации. Цифро-аналоговые 
(ЦАП) и аналого-цифровые преобразователи (АЦП) находят широкое применение в различных областях современной науки и техники. Предлагается использовать на занятиях физики и смежных дисциплин компьютер, как универсальный электроизмерительный прибор, в основе которого используются АЦП и ЦАП звукового адаптера с акцентом на использование элементов, средства и принципы программирования в его программном обеспечении.

В исследовании рассматривается два аспекта: методика обучения физике, приобретения профессиональных компетенций техников-программистов.

Ключевые слова: аудиоадаптер; программы-эмуляторы; реальный и виртуальный учебный физический эксперимент; профессиональные компетенции; профессиональная компетентность.

\title{
USAGE OF THE PROGRAMS-EMULATORS WHILE STUDYING PHYSICS BY THE FUTURE ENGINEER-PROGRAMMERS
}

\author{
Ruslan B. Tychuk \\ teacher of the highest category \\ Vinnytsia College NUFT, Vinnytsia, Ukraine \\ ruslantytchuk@mail.ru \\ Sergii D. Petrovych \\ $\mathrm{PhD}$ (pedagogical sciences), teacher of the highest category \\ Vinnytsia College NUFT, Vinnytsia, Ukraine \\ politex2004@rambler.ru
}

\begin{abstract}
A modern gauge has been fused with digital and processor means of managing and processing information. Digital-to-analog (DACs) and analog-to-digital converters (ADCs) are widely used in various fields of modern science and technology. It is proposed to use the computer on the physics lessons and related subjects as the universal electric measuring device, which is based on using ADC and DAC audio adapter with an emphasis on the use of elements, means and principles of programming in its software.

The study considers two aspects: methodology of teaching physics, gaining the professional competencies by engineer-programmers.
\end{abstract}

Keywords: audio adapter; programs-emulators; real and virtual educational physical experiment; professional competences; professional competency.

\section{REFERENCES (TRANSLATED AND TRANSLITERATED)}

1. Bespalov P. V. Computer competence in the context of student-centered learning / P. V. Bespalov / Pedagogy. - 2003.- № 4. - P. 45-50. (inRussian)

2. Vinnyk M. O. Formation of research competence of students of specialty "Software Engineering" the example of teaching "Group dynamics and communication» / M. O. Vinnyk, N. V. Osypova, Yu. H.Tarasich, A. P. Savenko // Naukovi pratsi [Chornomorskoho derzhavnoho universytetu imeni Petra Mohylykompleksu «Kyievo-Mohylianskaak ademiia»]. Seriia :Pedahohika. - 2014. - T. 245, Vyp. 233. 95-101s (inUkrainian).

3. Industry standards of higher education of Ukraine. Educational Qualifications Bachelor characteristics. Areas of expertise 0403 System sciences and cybernetics. Direction 040302 Information. Ministerstvo osvity i nauky Ukrainy. - K., 2010. - 32 s(in Ukrainian).

4. Dyma Ya. Methodological aspects of the programs, emulators of measuring devices in demonstration experiment at physics lessons / Ya. Dyma, O. Saienko // Naukovi zapysky Ternopilskoho natsionalnoho pedahohichnoho universytetu im. V. Hnatiuka. Ser. Pedahohika / hol. red. H. Tereshchuk. - Ternopil, 2011. - \# 1. - S. 135-140 (in Ukrainian).

5. Dyma Ya. Yu. Carrying out laboratory works on physics using interactive methods and computer technology / Ya. Yu. Dyma, O. P. Rudenko, O. V. Saienko // Zbirnyk naukovykh prats Umanskoho derzhavnoho pedahohichnoho universytetu imeni Pavla Tychyny. - Uman : PP Zhovtyi O. O., 2009. Ch. 2. - S. 99-106 (in Ukrainian). 
6. Lavrova A.V. The approach to the organization and conduct of the training school physics experiment / Lavrova A.V, Zabolotnyi V.F.// Informatsiini tekhnolohii i zasoby navchannia, 6 (50). (2015), 57-70s (inUkrainian).

7. Leontian M. A. The concept of "competence" and "competence" in the theory of education / M. A. Leontian // Naukovi pratsi Chornomorskoho derzhavnoho universytetu imeni Petra Mohyly kompleksu "Kyievo-Mohylianska akademiia"]. Ser.:Pedahohika. - 2012. - T. 188, Vyp. 176.-S.73-75.-Rezhym dostupu: http://nbuv.gov.ua/UJRN/ Npchduped_2012_188_176_18(in Ukrainian).

8. Osypova N. Model research competence formation of future software engineers [Tekst] / N. Osypova, M. Vinnyk, Yu. Tarasich // Informatsiini tekhnolohii v osviti. - 2014. - Vyp. 20. - S. 150-159 (inUkrainian).

9. Petrovych S. D. Formation of professional competence of future specialists in computer science in the study of special subjects in technical colleges: Dys. kand. ped. nauk: 13.00.04/S.D. Petrovych; Vinnyts. derzh. ped. un-t im. M. Kotsiubynskoho. - Vinnytsia, 2011. - 255 s (inUkrainian).

10. Radelchuk H. I. Formation of professional competence of the modern software engineer // Zbirnyk naukovykh prats fakultetu prykladnoi matematyky ta kompiuternykh tekhnolohii Khmelnytskoho natsionalnoho universytetu.- Khmelnytskyi:KhNU.- \# 1 (2).- 2009. - S. 142-147(inUkrainian).

11. Shchedrolosiev D.Ye. Competence approach to the training of software engineers [online] //D.Ye. Shchedrolosiev, 2011, Informatsiini tekhnolohii i zasoby navchannia. 2011. \#4 (24). Available from: http://www.journal.iitta.gov.ua(in Ukrainian).

Conflict of interest. The authors have declared no conflict of interest.

\section{$(\mathrm{Cc})$ BY-NC-SA}

This work is licensed under Creative Commons Attribution-NonCommercial-ShareAlike 4.0 International License. 